\title{
Special Thanks
}

\author{
細矢治夫 ${ }^{\mathrm{a}, \mathrm{b}}$ \\ ${ }^{\mathrm{a}}$ 日本コンピュータ化学会 会長 \\ ${ }^{\mathrm{b}}$ 打茶の水女子大学名誉教授, $=112-0012$ 東京都文京区大塚 2 丁目 $1-1$ \\ e-mail: hosoya.haruo@ocha.ac.jp
}

(Received: September 16, 2011; Accepted for publication: October 14, 2011; Advance publication: December 31, 2011)

本日, 日本コンピュータ化学会が創立10周年の記念事 業を会場の皆様方と無事迎えることができたことを, 会 員一同と共に喜び祝いたいと思います.

本学会は, 10年前に化学ソフトウエア学会と日本化学 プログラム交換機構の合併によって発足したものである ので, 本学会の歴史とそこに積み上げられた成果は, こ の 10 年間の会員の皆様の御努力だけでなく, 前身の両団 体の長い歴史とそれを支えて来られた多くの方々の献身 的な御努力を無視して語り, 評価することはできませ h.

しかし, 今日御出席の皆様方は私共と御一緒にこの祝 いを共有できるのですが，今日ここに抢られない方々に は，それが叶いませんので，その方々の扔名前をここに 挙げて, 特別の感謝の気持ちを表したいと思います.

先ず，化学ソフトウエア学会の下沢隆前初代会長がお られます。 その下沢先生からは, 現在病気療養中で出席 できないので皆様方によろしくとのメッセージを承って おります. また, 同学会の吉村忠与志事務局長の奥様に は, 学会以前の化学ソフトウエア研究会以来長年にわ たって事務局を献身的に支えて来られたことに感謝の念 を禁じえません。

日本化学プログラム交換機構の側では，その事務局を
初めから扔一人で切り盛りされて来られた佐々木透さん は, 徹頭徹尾裏方に徹して来られました。 その佐々木さ んに対しては本当に頭の下がる思いで一杯です.

ベストシステムズの西克也氏は, 採算を度外視して本 学会の事務局の場所の提供を頂くと共に財政的にも特別 の便宜を計らって頂いたことに深甚の感謝を申し上げま す．また，同社の曾々木志穂さんには，本学会の設立当 初から事務局の雑務を一人でさばいて来られたことに感 謝を致します。

また, カナダのモンクトン大学のブライアン・ニュー ボルト先生には, 雑誌の英文校閲を初めから今日まで喜 んで御担当頂いたことに感謝を捧げます。

ひょっとして，私が失念してここに打名前を出せな かった方が扔られるかも知れませんが, 申し訳なくも, その方々にも厚く御礼申し上げる次第であります.

以上は, 本学会のこれまでの活動に対する御協力御援 助に対する感謝の言葉でありますが, 本学会の今後の 10 年20年の活動を支えて頂くであろう諸々の方々様へも, この場を借りて予めの感謝の意を扔伝えしたいと思いま す. 本学会の会員一同様へも従前と同様の御協力を㹉 いしたいと存じます.

2011年6月16日 記 